\title{
Peyzaj Mimarlığı Uygulama Alanlarında İş Sağlığı ve Güvenliği: Ankara Örneğinde Şantiye Hizmetlerinin Değerlendirilmesi
}

\author{
Umut GÜLER ${ }^{1 *}$
}

\author{
${ }^{1}$ Ankara Üniversitesi, Ziraat Fakültesi, Peyzaj Mimarlığı Bölümü,06110, ANKARA
}

Öz

Son yüzyılda, teknolojik gelişmelere paralel olarak sanayileşmedeki hızlı artış, iş kazalarına da yansımaktadır. İş sağlığı ve güvenliği, insanlığın çalışma gereksinimi duymaya başlamasından beri kavramsal olarak karşımıza çıkmaktadır. İlkel toplumlardan günümüze iş bölümü yapılmakta ve yapılan işlerde standartlaşma ve çeşitlilik, işçi sağlığı ve güvenliğini zorunlu duruma getirmektedir. Peyzaj mimarlığı uygulama alanlarında yürütülen her proje birbirinden farklı iş gücü, teknik ve mekânlar içermekte ve bu farklılıklara bağlı olarak çalışanlar açısından farklı risk ve tehlikeler meydana getirmektedir. Bu çalışmada peyzaj mimarlığı alanında iş sağlığı ve güvenliği ile ilgili tanımları ortaya koyarak mevzuat ve uygulamaya yönelik gelişim aşamalarının Türkiye'de nasıl ilerlediği irdelenmektir. Bu amaçla peyzaj mimarlığı uygulama alanlarında şantiye personelinin iş sağlığı ve güvenliği konusuna bakışı ele alınmaktadır. Personelin kendi sorumluluklarını içeren mevzuatları ne kadar takip ettikleri ve ne kadar uygulamaya aktarabildikleri sorgulanmaktadır. Ayrıca, alan çalışmalarında iş sağlı̆̆ı ve güvenliğinin uygulanabilirliği yönüyle dikkat edilmesi gereken konular irdelenmektedir. Bu kapsamda Ankara İlinde seçilen şantiye alanında gözlem yapılarak personel ve yöneticilerle görüşülmüştür. Peyzaj uygulama hizmetlerinde görev yapan personelin konuyla ilgili görüşleri alınarak kendi sorumluluklarını içeren mevzuatları ne kadar takip ettikleri ve ne kadar hayata geçirdikleri sorgulanmıştır. Peyzaj uygulama hizmetlerinde iş sağlığı ve güvenliğinin uygulanabilirliği yönünden dikkat edilmesi gerekenler bakımından çözüm önerileri geliştirilmiş ve çalışma sonucunda ortaya çıkan bilgiler ışığında geleceğe yönelik önerilerde bulunulmuştur.

Anahtar Kelimeler: İş sağlığı ve güvenliği, iş güvenliği uzmanlığı, peyzaj mimarlığı uygulama hizmetleri

\section{Occupational Health and Safety in Landscape Applications: Evaluation of Worksite Services Such as Ankara}

\begin{abstract}
In the last century, the rapid increase in industrialization in parallel with technological developments is also reflected in occupational accidents. Occupational health and safety has been confronting us conceptually since it started to feel the need. From primitive societies to the present, division of labor has been made and standardization and diversity in the works make worker health and safety mandatory. Each project carried out in the application areas of landscape architecture includes different workforce, techniques and spaces and creates different risks and dangers for employees depending on these differences. This study is to examine how to progress in the field of landscape architecture in occupational health and safety related definitions of the stages of development in Turkey for putting forth legislation and practice. For this purpose, the perspective of the construction site personnel on occupational health and safety is discussed in the application areas of landscape architecture. It is questioned to what extent the personnel follow the regulations including their own responsibilities and how much they can put into practice. In addition, issues that need to be considered in terms of the applicability of occupational health and safety in field studies are examined. In this context, observations were made in the selected construction site in Ankara Province and the staff and managers were interviewed. Taking the opinions of the personnel working in landscape application services on the subject, it was questioned to what extent they followed the legislation containing their responsibilities and to what extent they implemented them. In terms of the applicability of occupational health and safety in landscape application services, solution suggestions were developed and futureoriented suggestions were made in the light of the information obtained as a result of the study.
\end{abstract}

Keywords: Occupational health and safety, occupational safety specialist, landscape architecture practice services 


\section{Giriş}

Son yüzyılda, sanayileşmenin hızlı artışı ve teknolojik gelişmelere paralel olarak iş kazalarında da hızlı bir artış yaşanmış; çevresel sorunların yanında büyük sosyo-ekonomik kayıplar ortaya çıkmıştır (Arseven, 2004). İş sağlığı ve güvenliği, insanlığın çalışma gereksinimi duymaya başlamasından beri kavramsal olarak karşımıza çıkmaktadır. İlkel toplumlardan günümüze iş bölümünün ortaya çıkması, yapılan işlerde standartlaşma ve çeşitlilik, işçi sağlı̆̆ ve güvenliğini zorunlu duruma getirmiş ve özellikle sanayi devrimi ile birlikte yoğunlaşan iş kazalarının nedenlerinin tartışılarak tanımlanması gerekliliğini ortaya çıkarmıştır (Çiçek ve Öçal 2015).

Dünya Sağlık Örgütü (WHO) tarafından ortaya konulan ve genel olarak kabul edilen iş sağlığı ve güvenliği tanımı; bir bireyin sadece fiziksel değil aynı zamanda ruhen ve sosyal açılardan da tam bir iyilik halinde olması olarak tanımlamaktadır. Ayrıca çalışanlara en iyi sağlık koşullarının sağlanarak bu durumun süregelmesi faaliyetlerini de ifade etmektedir (URL- 1). Başka bir tanımla iş sağlığı ve güvenliği, çalışma şartlarını ve üretim araçlarını sağlığa uygun hale getirmek, çalışanları çalışma ortamlarının tüm zararlı etkilerinden koruyarak işin ve işçinin birbirine uyumunu sağlamak üzere kurulmuş, mühendislik ve tıp disiplinlerini temel alan entegre bir bilim dalıdır (URL- 1).

Uluslararası Çalışma Örgütü (ILO), 1950 yılında mevcut İSG tanımına, çalışanların sağlık ve refahlarının yükseltilmesi; işyeri koşullarının iyileştirilmesi, çevrenin korunarak üretimin gerçekleştirilmesi, ürünlerin ve üretim süreçlerinin oluşturacağı sağlık sorunlarının ortadan kaldırılması, çalışanların uygun işlerde çalıştırılması ve ihtiyaçlara göre uygun iş ortamının düzenlenmesi gibi maddeler eklemiştir (Yılmaz, 2009).

Ülkelerin sanayileşmesi ile doğru orantılı olarak çalışanların güvenli biçimde çalışmalarının sağlanması, çözümü gereken en önemli problemlerden birisi olarak karşımıza çıkar. Toplumdaki tüm bireylerin faydalandığı sanayileşmenin ve teknolojik ilerlemenin bedelini çalışanlara ödetmeme kaygısı çağdaş ve modern toplumların başlıca amaçlarından biridir. Bu nedenle uluslararası hukukta da olduğu gibi Türk İş Hukukunda da iş sağlığı ve güvenliği konusuna özel olarak önem verilmiş, başta 6331 sayılı İş Sağlığı ve Güvenliği Kanunu olmak üzere bu yönde pek çok düzenleme yapılarak; çalışanların, işverenlerin ve işveren vekillerinin sorumluluk sınırları belirlenmiştir (Medeni, 2014).

İş sağlığ1 ve güvenliği kavramı çalışanlar için önemli olduğu kadar ülke ekonomisi için de son derece önemlidir. İş kazalarının ve meslek hastalıklarının artması ile birlikte iş gücü, milli servet ve iş verimi azalmaktadır (Medeni, 2014). Gerek (1998)' in belirttiğine göre, işçi ve işverenin uğradığı zararların yanı sıra, ülke ekonomisi açısından da ortaya çıkabilecek sonuçlar çarpıcıdır. Özellikle yetişmiş insan gücü kaybı, sosyal güvenlik primlerindeki kayıplar, çalışılmayan işgünü kayıpları, sosyal yardım harcamalarında artışlar en çok dikkat çeken noktalardır (Bıyıkçı, 2010).

İş sağlığı ve güvenliğinin en temel amacı, iş yerinde meydana gelebilecek kazaların önlenebilmesidir. Kazaların önlenmesi ise çalışanların performansının ve işyerinde kullanılan araç gereçlerin kontrol edilmesiyle mümkündür. İş yerinde kullanılan bütün araç ve gereçler birtakım tehlikeler içerir. Bu tehlikelere karşı alınabilecek önlemlerin tespiti iş güvenliği alanına girer. Oğuz (2011)' a göre, güvenlik; ölüme, hastalığa, hasarlara ve kazalara karşı koruma ile ilgilidir. Çalışanların korunmadığı bir ortamda ekonomik ilerleme ve verim beklenemez (Medeni, 2014). Hem ekonomik hem de sosyal bir problem olarak karşımıza çıkan iş göremezlik hali, iş gücümüzde önemli oranda kayıplar ortaya çıkarmaktadır. Koruyucu tedbirler için yapılan masraflar, kazalar sonunda ödenen tazminatlardan çok daha az maliyetlidir. İş güvenliği, çalışanların vücut bütünlüğüne gelebilecek tehlikeleri bertaraf etmeyi hedefler. Bu konu işverenler açısından da önemli bir konu olmakla beraber, çalışanlara güvenli bir çalışma ortamı sağlamak, insancıl sebeplerin dışında işletme maliyetleri açısından da önemli olmaktadır. İş sağlığı ve güvenliğini sağlamak için yapılan yeterli harcama, kazanın oluşma ihtimalinin azalmasına, üretim maliyetinin düşmesine ve karın daha fazla olmasına neden olmaktadır (Bozkurt, 1993). İşletmelerin İSG için yaptıkları harcamalar, maliyetlerin artması ile sonuçlanacaktır. Ancak uzun vadede yapılan bu harcamalar, kaza ve hastalıkların oluşturacağı kayıplardan daha az olacaktır (Ünsar, 2003). Gelişmiş ülkelerde kullanılan iş kazası maliyet hesaplama yöntemleri, kaza maliyetinin yapılan kazanın gerçekleşmemesi için yapılan harcamadan çok daha fazla olduğunu göstermiştir (Güyagüler, 2007).

Uluslararası Çalışma Örgütü (ILO) verilerine göre dünyada 3 milyar işgücü bulunmaktadır. Bu işgücünün oluşturduğu işlerde;

- Her 15 saniyede 153 işçi, sağlı̆̆ında önemli etkiler bırakan iş kazalarına maruz kalmakta;

- Her gün 6 bin 300 kişi, iş kazası ya da meslek hastalığı nedeniyle hayatını kaybetmektedir. Bu ölümlerin bini iş kazası, 5 bin 300'ü meslek hastalığıdır.

- Her yıl 350 bin kişi ölümlü iş kazası geçirmekte, 2 milyon kişi meslek hastalıkları nedeniyle yaşamını yitirmekte; 
- 270 milyonu aşkın iş kazası meydana gelmekte ve 160 milyon kişi meslek hastalıklarına yakalanmaktadır.

- Her yıl zehirli maddelere maruz kalan 651 bin işçi yaşamını yitirmekte,

- $\quad$ 1970'lerde asbest kullanımı yasaklanmasına rağmen her yıl asbestle çalışma alanlarında 100 binden fazla kişinin yaşamını yitirdiği belirtilmektedir (URL-2).

ILO’nun açıklamalarına göre; tüm dünyada en önemli istihdam sektörü olan inşaat faaliyet alanlarında diğer sektörlere oranla daha fazla sayıda iş kazası yaşanmaktadır. İnşaat sektörü çalışma alanlarında mekanizasyon artmasına rağmen el emeği hala büyük ölçüde önem taşımaktadır. Yine ILO verilerine göre; tüm dünyada inşaat faaliyet alanında her yıl 60 bini aşkın ölümcül kaza meydana gelmekte ve bununla birlikte her 10 dakikada bir kişi iş kazası nedeniyle yaşamını yitirmektedir (URL-2). Ancak yapılan araştırmalar da göstermektedir ki, iş kazalarının \%81’i insan hatası, \%17‘si işyeri ortamı koşulları ve \%2‘si önlenemeyen nedenlerdir. Güvercin (2005), bu sonuçlara göre iş kazalarının \%98'nin önlenebilir olması, İş sağlı̆̆ı ve güvenliği (İSG) konusunun önemini ve bu konuda yeterli, etkin önlemler alındığı takdirde iş kazası ve meslek hastalıklarının önemli oranda azaltılabileceğini belirtmektedir (Bıyıkçı, 2010).

İş kazaları, insan kaynaklı, makine kaynaklı, ortam- çevre kaynaklı ve yönetim kaynaklıdır. İş kazalarının oluşmasında üretim teknolojisi, üretim araçları ve çevre koşullarının yanında psikolojik, sosyolojik ve fizyolojik gibi birçok konu etken olmaktadır. Bu etkenler iki grupta toplanabilir. Bunlar; çalışma ortamlarındaki güvensiz davranışlar ve emniyetsiz durumlardır (URL-2). Emniyetsiz durumlar, çalışma ortamında iş güvenliğini bozan ve iş ortamında tehlikeli hale gelen eski teknoloji, bakımsız, kontrolsüz alet, ekipman, makinelerden ve sağlıksız çevre koşullarından kaynaklanmaktadır. Güvensiz davranışlar ise çalışanların psikolojik, fizyolojik ve sosyolojik durumları ile doğrudan ilgili olup çalışanın hatalı durum ve davranışlarından kaynaklanmaktadır. Emniyetsiz durumlara neden olanların en başında üretim sürecinde kullanılan makine ve ekipmanın niteliği gelmektedir. Sürekli yenilenen teknolojiyi takip edemeyen ve eski teknolojiyi kullanan üretim yerlerinde iş kazaları daha fazla görülmektedir (URL-2).

Tablo 1. İşyerinde karşılaşılan güvensiz durum ve davranışlar

\begin{tabular}{ll}
\hline & - Güvensiz çalışma yöntemi \\
& - Elektrikle çalışan topraklanmamış makinalar \\
& - Güvensiz ve sağlıksız çevre koşulları \\
& - Tehlikeli yükseklikte istifleme \\
Emniyetsiz Durumlar & - Yapılan işe uygun olmayan el aletleri \\
& - Kontrol ve testleri yapılmamış basıçlı kaplar ve kaldırma makinaları \\
& - Çalışma alanında kapatılmamış boşluklar \\
& - Koruyucusuz makine ve tezgâhlar \\
& - İşyeri düzensizliği \\
\hline & - İşi bilinçsiz yapmak, \\
& - Makina koruyucularını çıkarmak \\
& - Dalgınlık ve dikkatsizlik \\
& - Tehlikeli hızla çalışmak \\
& - Kişisel koruyucu ekipman kullanmamak \\
& - İş disipline uymamak \\
& - Görevi dışında iş yapmak \\
& - Yetkisiz ve izinsiz olarak tehlikeli bölgede bulunmak \\
Güvensiz Davranışlar & - Ehliyetsiz ve tehlikeli hızda araç kullanmak \\
\hline Güvensiz Davranışlar & - İşe uygun makina ve alet kullanmamak \\
\hline
\end{tabular}

Çalışanların iş düzeni tekdüze özellikler göstermeye başladığında çalışanda dalgınlık ve dikkatsizlik meydana gelmekte ve güvensiz davranışları ortaya çıkmaktadır. $\mathrm{Bu}$ koşullarda iş kazalarının meydana gelmesi engellenememektedir. Çalışanın yapması gereken iş için gerekli beceri ve tecrübeyi kazanmamış olması, yaptığ kendisine zor ya da sevimsiz gelmesi, çalışanın kişilik özellikleri önemsenmeden iş verilmesi yine güvensiz davranışları ortaya çıkarmaktadır. İşe uygun çalışan ya da çalışana uygun iş düzeninin oluşturulmamış olması iş kazalarının nedenlerine kaynaklık etmektedir (URL-2).

İş sağlığı ve güvenliği konusunu, çalışma ortamında bulunan makine ve ekipmanlar, kullanılan teknoloji, kişisel koruyucu ekipmanların kullanımı, ergonomi, iş yerindeki organizasyon yapısı, çalışanın yaşı, eğitimi gibi konular 
etkilemektedir. Ayrıca işyerinin fiziksel ortamı (gürültü, toz, sıcaklık, aydınlatma yeterliliği, havalandırma gibi) ve coğrafik özellikleri de İSG konusuna etki etmektedir (Yılmaz, 2009).

İnşaat sektörünün bir parçası olan peyzaj mimarlığı uygulama hizmetlerinde de yukarıda bahsi geçen konular sebebiyle iş kazaları meydana gelmektedir. İnşaat-yapı kelimesinin sözlük anlamlarından biri yapılmakta olan konut, köprü, yol vb. diğer bir anlamı da inşaat, konstrüksiyon yapma, oluşturma, meydana getirme olarak verilmektedir. Mimarlık sözlüğünde ise yapı; karada veya suda, bayındırlık ya da iskân tanımıyla, kurulan köprü, yol, tünel, baraj, bina gibi tesisler ile bunların yer altı ve yer üstü inşaatı olarak tanımlanmaktadır (URL-3).

"Yapı" kelimesinin Peyzaj Mimarlığı hizmetlerinde de algılanışı ve kullanımı benzerdir. Ancak peyzaj mimarları, yapı mimarlarının ve iç mimarların temel çalışma alanları olan yapılar (binalar) dışında kalan ve çoğunlukla açık alanlarda yer alan yapı ya da yapısal unsurlarla da ilgilidir. Bunlar; meydanlar, yaya yolları, spor alanları, çok amaçlı amfiler, oyun alanları, asmalı germeli sistemler, havuzlar, merdivenler, duvarlar, kanal ve drenaj sistemleri, peyzaj donatı elemanları ve döşemelerdir (URL-3). Peyzaj mimarlı̆̆ sadece bitkisel peyzaj çalışmalar ile ilgili değildir; aynı zamanda inşaat hizmetlerine bağlı yapısal peyzaj ile de ilgilenir.

2004 yılında Resmi Gazetede yayınlanan ‘Isş Güvenliği ile Görevli Mühendis veya Teknik Elemanların Görev, Yetki ve Sorumlulukları ile Çalışma Usul ve Esasları Hakkındaki Yönetmeliğin’ de iş güvenliği uzmanı, Çalışma ve Sosyal Güvenlik Bakanlığı tarafından sertifikalandırılmış, iş güvenliğgi ile görevli mühendis ya da teknik eleman olarak tanımlanmıştır. Yine aynı maddede üniversitelerin inşaat, jeoloji, kimya, endüstri, metalürji, maden, elektrik, makine, elektronik, jeofizik, bilgisayar, fizik, tekstil, gemi, çevre, gıda mühendisliği, mimarlık ve petrol mühendisliği bölümleri ile ziraat fakültelerinin tarım makineleri bölümünden mezun olanlar mühendis kabul edilmiştir. Ayrıca üniversitelerin, iş sağlığı ve güvenliği bölümleri ve Teknik Eğitim Fakültelerinden mezun olanlar da teknik eleman olarak kabul edilmiştir. İlk olarak 2012 yılında Resmi Gazetede yayınlanan 'İş Güvenliği Uzmanlarının Görev, Yetki, Sorumluluk ve Eğitimleri Hakkında ki Yönetmelik’ te, 2013 yılında değişiklik yapılmış ve iş güvenliği uzmanı tanımı tekrar yapılmıştır. Buna göre, İş sağlığı ve güvenliği çalışmalarında görev almak üzere Bakanlıkça yetkilendirilmiş, iş güvenliği uzmanlığı belgesine sahip, Bakanlık ve ilgili kuruluşlarında çalışma hayatını denetleyen müfettişler ile mühendislik ve mimarlık eğitimi veren fakültelerin mezunları olarak tanımlanmıştır (URL-4).

Peyzaj mimarları ise; 12 Temmuz 2013 tarihine kadar teknik eleman listesindeki meslekler arasında bulunmamakta, İş Güvenliği Uzmanlığı sınavına girememekte ve İş Güvenliği Uzmanı olmasına gerekçesiz olarak izin verilmemekteydi. Peyzaj Mimarları Odası ve peyzaj mimarları Çalışma Bakanlığına konu ile ilgili dava açmış ve peyzaj mimarları lehine sonuçlanmıştır. İlgili kanun değişikliği TBMM Genel Kurulu tarafindan 12 Temmuz 2013 tarihinde onaylanmış ve iş güvenliği uzmanı tanımında değişiklik yapılmışıır (URL-5).

İnşaat ve peyzaj mimarlığı alanlarında yürütülen her projenin uygulamaları, birbirinden farklı iş gücü, teknik ve mekânlar içermektedir. Bu farklılıklara bağlı olarak çalışanlar açısından farklı risk ve tehlikeler meydana getirmektedir.

Türkiye de gelişmekte olan bir ülke olarak iş kazası, ölüm, yaralanma ve meslek hastalıkları istatistikleri ile karşılaşılmaktadır. Bu istatistik hizmetleri ile Sosyal Sigortalar Kurumu (SGK) ve Türkiye İstatistik Kurumu (TÜIK) ilgilenmektedir.

SGK tarafından gerçekleştirilen istatistik çalışmalarında, peyzaj uygulama çalışmaları 2014 yılına kadar 'Bina ve Çevre Düzenleme Faaliyetleri' adı altında bina temizliği ile beraber toplam bir rakam olarak gösterilmiştir. 2014 yılında yine aynı kodun altında fakat alt madde açılarak 'Çevre Düzenleme ve Bakım Faaliyetleri' olarak ayrıca hesaplamalar yapılmıştır. Bu çalışmada yıllara göre karşılaştırma yapabilmek için 2014-2019 yılları arasında bulunan 'Çevre Düzenleme ve Bakım Faaliyetleri' adı altında geçen istatistiki bilgiler göz önünde bulundurulacaktır.

Türkiye İstatistik Kurumu (TÜİK) ve Sosyal Güvenlik Kurumu (SGK) istatistiklerine göre meslek hastalı̆̆ı, kaza ve ölüm oranı en yüksek sektörlerin başında inşaat sektörü gelmektedir. SGK verilerine göre kaza oranı en yüksek 13 faaliyet grubu seçilmiştir. 'Diğer faaliyet grupları' adı altında geçen grup, seçilen 13 faaliyet grubu dışında kalan tüm faaliyet gruplarının toplamıdır. Tablo 2' de SGK'nın 2014- 2019 verilerine göre kaza oranının yüksek olduğu çeşitli faaliyet alanlarının sigortalı işçi sayısına göre belirlenen iş kazası sayıları verilmektedir. Bu tabloda 'Çevre Düzenlemesi ve Bakım Faaliyetleri ' çalışmalarında önemli ölçüde iş kazasına rastlandığı görülmektedir (URL-6). 
Tablo 2. SGK 2014- 2019 yılı faaliyet alanına göre aktif çalışan iş kazası sayısı

\begin{tabular}{|c|c|c|c|c|c|c|c|}
\hline \multirow[t]{2}{*}{ No } & \multirow[t]{2}{*}{ Faaliyet Grupları } & \multicolumn{5}{|c|}{ Yıllara Göre İş Kazası Sayısı } & \multirow[b]{2}{*}{2019} \\
\hline & & 2014 & 2015 & 2016 & 2017 & 2018 & \\
\hline 1 & $\begin{array}{l}\text { Makine ve teçhizat hariç, fabrikasyon } \\
\text { metal ürünleri imalatı }\end{array}$ & 18.529 & 19.221 & 20.616 & 23.627 & 25.716 & 24.085 \\
\hline 2 & Bina İnşaatı & 13.508 & 15.065 & 20.159 & 34.952 & 41.759 & 25.551 \\
\hline 3 & Ana Metal Sanayi & 12.357 & 12.529 & 13.081 & 15.670 & 17.403 & 16.413 \\
\hline 4 & Gıda Ürünlerin İmalatı & 10.971 & 12.003 & 14.351 & 20.270 & 22.610 & 22.734 \\
\hline 5 & $\begin{array}{l}\text { Diğer Metalik Olmayan } \quad \text { Mineral } \\
\text { Ürünlerin İmalatı }\end{array}$ & 10.244 & 10.242 & 11.721 & 14.183 & 15.622 & 13.432 \\
\hline 6 & Kömür ve Linyit Çıkarılması & 10.026 & 7.429 & 8.274 & 8.468 & 8.399 & 8.983 \\
\hline 7 & Yiyecek ve içecek hizmeti faaliyetleri & 8.818 & 10.458 & 12.626 & 16.284 & 22.487 & 25.969 \\
\hline 8 & Özel İnşaat Faaliyetleri & 8.516 & 10.393 & 14.877 & 6.977 & 7.759 & 6.223 \\
\hline 9 & Bina dışı yapıların inşaatı & 7.675 & 7.903 & 9.516 & 20.873 & 27.639 & 15.927 \\
\hline 10 & $\begin{array}{l}\text { Kara taşımacılığ } 1 \text { ve boru hattı } \\
\text { taşımacılığ }\end{array}$ & 7.287 & 7.117 & 7.246 & 8.353 & 8.917 & 9.039 \\
\hline 11 & $\begin{array}{l}\text { Çevre Düzenlemesi ve Bakım } \\
\text { Faaliyetleri (Peyzaj Uygulama İşleri) }\end{array}$ & 586 & 779 & 966 & 1.271 & 1.615 & 1.845 \\
\hline 12 & $\begin{array}{l}\text { Başka yerde sınıflandırılmamış makine } \\
\text { ve ekipman imalatı }\end{array}$ & 5.415 & 5.937 & 6.276 & 8.102 & 9.815 & 9.592 \\
\hline 13 & Diğer madencilik ve taş ocakçılığı & 1.557 & 1.639 & 2.045 & 2.537 & 2.806 & 2.435 \\
\hline 14 & Diğer Faaliyet Grupları & 100.075 & 112.639 & 144.314 & 178.086 & 202.411 & 240.235 \\
\hline & Toplam & 221.366 & 241.547 & 286.068 & 359.653 & 430.985 & 422.463 \\
\hline
\end{tabular}

Türkiye'de 2006 yılından sonra SGK'ya iş kazalarının bildirilmesi ve bu bildirimlerin sistemde kayıt altına alınmaya başlaması ile iş kazası istatistiki verileri somut bir şekil almıştır. Bu verilerin çok yüksek rakamlar olması nedeniyle iş sağlığı ve güvenliğine ilişkin alınan önlemler ve bu çerçevede yürütülen faaliyetlere hız kazandırılmıştır

Tablo 3'te SGK'nın 2014-2019 verilerine göre kaza oranının yüksek olduğu çeşitli faaliyet alanlarında ölen sigortalı işçi sayıları verilmektedir (URL-6).

Tablo 3. SGK 2014- 2019 yılı verileri ile ölümle sonuçlanan iş kazası sayılarının faaliyet alanlarına göre dağılımı

\begin{tabular}{|c|c|c|c|c|c|c|c|}
\hline \multirow[t]{2}{*}{ No } & \multirow[t]{2}{*}{ Faaliyet Grupları } & \multicolumn{6}{|c|}{ Ölen sigortalı sayısı } \\
\hline & & 2014 & 2015 & 2016 & 2017 & 2018 & 2019 \\
\hline 1 & Makine ve teçhizat hariç fabrikasyon metal ürünleri imalatı & 31 & 37 & 27 & 36 & 48 & 31 \\
\hline 2 & Bina İnşaatı & 260 & 239 & 239 & 340 & 360 & 207 \\
\hline 3 & Ana Metal Sanayi & 14 & 21 & 30 & 29 & 43 & 19 \\
\hline 4 & Gıda Ürünlerin İmalatı & 30 & 23 & 32 & 41 & 38 & 27 \\
\hline 5 & Diğer Metalik Olmayan Mineral Ürünlerin İmalatı & 49 & 46 & 48 & 31 & 44 & 24 \\
\hline 6 & Kömür ve Linyit Çıkarılması & 335 & 26 & 11 & 31 & 11 & 13 \\
\hline 7 & Yiyecek ve içecek hizmeti faaliyetleri & 14 & 24 & 19 & 28 & 21 & 22 \\
\hline 8 & Özel İnşaat Faaliyetleri & 98 & 110 & 127 & 89 & 69 & 56 \\
\hline 9 & Bina dışı yapıların inşaatı & 143 & 124 & 130 & 158 & 162 & 105 \\
\hline 10 & Kara taşımacılığ ve boru hattı taşımacılığ 1 & 172 & 162 & 179 & 211 & 175 & 184 \\
\hline 11 & Çevre Düzenlemesi ve Bakım Faaliyetleri(Peyzaj İşleri) & 4 & 12 & 14 & 11 & 18 & 4 \\
\hline 12 & Başka yerde sınıflandırılmamış makine ve ekipman imalatı & 22 & 10 & 8 & 16 & 14 & 9 \\
\hline 13 & Diğer madencilik ve taş ocakçılığı & 38 & 40 & 64 & 38 & 33 & 28 \\
\hline \multirow[t]{2}{*}{14} & Diğer Faaliyet Grupları & 243 & 354 & 451 & 539 & 483 & 418 \\
\hline & Toplam & 1.626 & 1.252 & 1.405 & 1.633 & 1.519 & 1147 \\
\hline
\end{tabular}

Kaza ve ölüm oranlarının bu kadar yüksek olması nedeniyle son yıllarda Türkiye’ de birçok sektörde özellikle inşaat sektöründe; iş sağlığı ve güvenliği konusuna daha çok dikkat edilmeye başlandığı görülmektedir. Bu kapsamda, gerekli tüm önlemler (teknik, eğitim, denetim ve kontrol, kişisel koruyucu ekipman gb) alınmaya çalışılmakta, iş sağlığı ve güvenliği eğitimlerine büyük oranda önem verilmektedir. Buna rağmen ölüm oranları azaltılamamaktadır.

Bu durum Çevre Düzenleme ve Bakım Faaliyetlerinde’ de aynıdır. Son yıllarda inşaat sektöründe, ilgili kurumlarca verilen cezai yaptırımlardan dolayı iş sağlığı ve güvenliği konusuna daha çok önem verilmeye başlanmıştır. Peyzaj 
uygulama çalışmalarında ise gerek şantiye personelinin gerekse işçilerin iş sağlığı ve güvenliği konusuna yaklaşımlarının istenilen düzeye gelmediği düşünülmektedir.

Günümüzde peyzaj mimarlarının yaptıkları uygulama hizmetlerini anlayamayan, bilmeyen birçok meslek disiplini ve bireyler var olduğu görülmektedir. İnşaat mühendisleri ve mimarlar da dâhil olmak üzere peyzaj mimarlığı birçok kişi tarafından sadece bitkisel peyzaj uygulamaları yapan meslek olarak değerlendirilmektedir. Oysaki peyzaj mimarları proje aşamalarından itibaren tüm uygulama (yapısal-inşai ve bitkisel peyzaj) aşamalarını gerçekleştirir. Son olarak yaptıkları uygulama alanlarının bakım ve kontrol hizmetlerini de üstlenebilmektedir. Şekil 1'de bu süreç, İSG planlaması da dâhil edilerek detaylandırılmıştır.

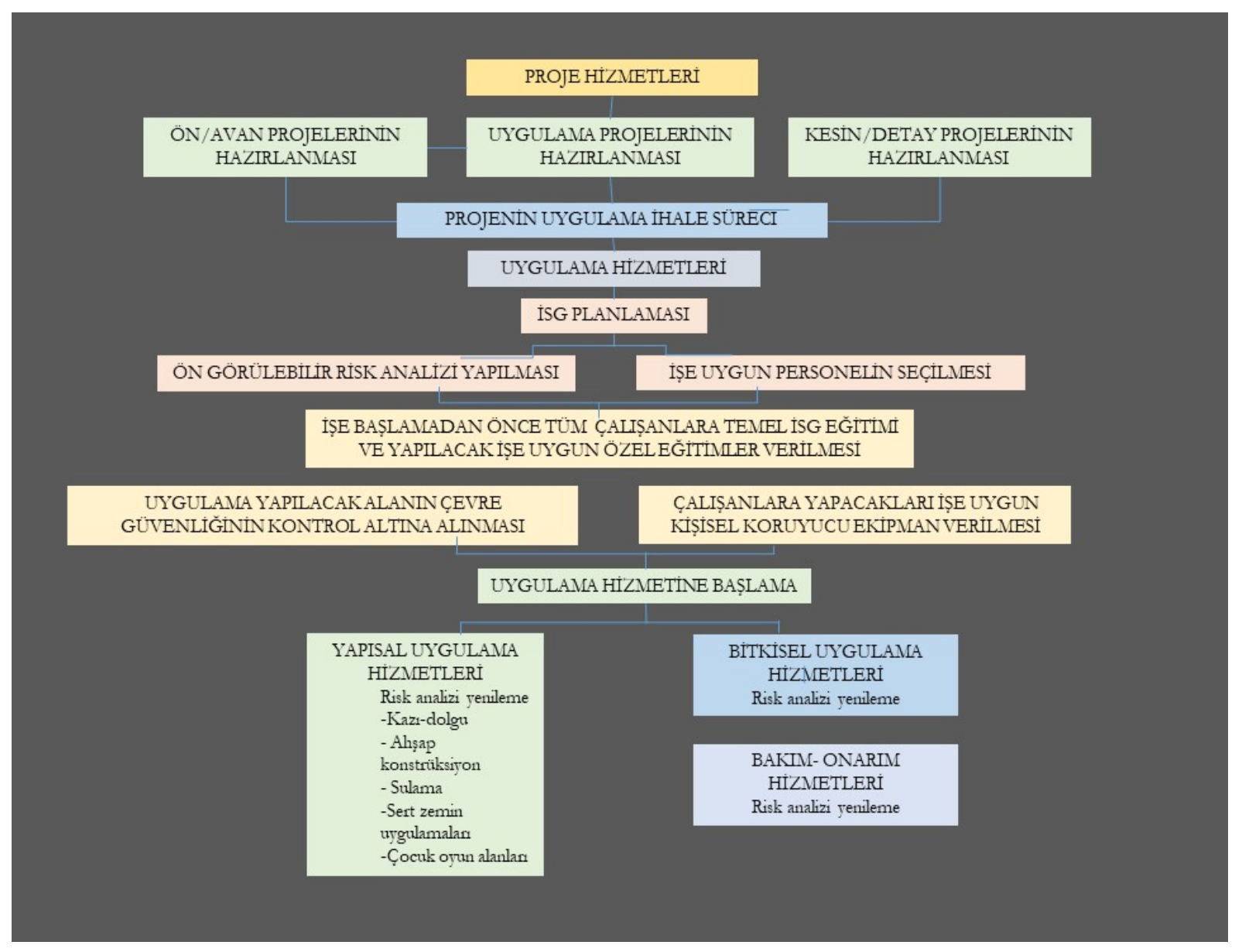

Şekil 1. Peyzaj mimarlığı proje ve uygulama hizmetleri (Orijinal)

Bu çalışma kapsamında peyzaj mimarlığı uygulama alanlarında iş sağlığı ve güvenliği konusu ele alınmaktadır. Peyzaj mimarlığı alanında çok sayıda çalışanı ile hizmet veren şantiye ve uygulama alanlarında iş sağlığı ve güvenliği konularında yapılması gerekenler tartışılmaktadır. Sonuçta çalışanların ve işverenlerin iş sağlığı ve güvenliği uygulama şekillerine dikkat çekilmek istenmektedir.

Ayrıca, Türkiye'de iş sağlığı ve güvenliğinin gelişimi ve bu gelişim çerçevesinde peyzaj mimarlığı alanında yürütülen uygulama örneği ele alınmaktadır.

Bu çalışma da peyzaj mimarlığı alanında iş sağlığı ve güvenliği ile ilgili tanımları ortaya koymak, mevzuat ve uygulamaya yönelik gelişim aşamalarının Türkiye'de nasıl ilerlediğini irdelenmektir. Bu amaçla peyzaj mimarlığı uygulama alanlarında şantiye personelinin iş sağlığı ve güvenliği konusuna bakışı ele alınmakta, personelin kendi sorumluluklarını içeren mevzuatları ne kadar takip ettikleri ve ne kadar uygulamaya aktarabildikleri sorgulanmaktadır. Ayrıca, alan çalışmalarında iş sağlığı ve güvenliğinin uygulanabilirliği yönüyle dikkat edilmesi gereken konular irdelenmektedir. Bu kapsamda örnek park alanı uygulama süreci gözlemlenerek iş sağlığı ve güvenliği bağlamında karşılaşılan sorunlar tartışılmaktadır. Gözlemler ve sözlü görüşmeler 1şığında geleceğe yönelik çözüm önerileri sunulacaktır. 


\section{Materyal ve Metot}

\subsection{Materyal}

$\mathrm{Bu}$ çalışma kapsamında peyzaj uygulama hizmetleri sırasında iş sağlı̆̆ ve güvenliği konusundaki mevcut durumun araştırılması ile birlikte birçok özel, tüzel ve uluslararası kuruluşun verileri incelenerek literatür çalışması yapılmıştır.

Bu çalışmanın ana materyalini, peyzaj mimarlığı uygulama hizmetleri sırasında çalışanların davranış biçimlerine dayalı gözlem ve çalışanlar ile yapılan sözlü görüşme sonuçları oluşturmaktadır. Çalışanların konu ile ilgili olarak farkındalıklarını ortaya koymak ve davranış biçimlerini inceleyebilmek için Ankara İlinde bulunan ve peyzaj uygulama hizmetlerini yürüten firmaların konuya yaklaşımları ele alınmıştır.

\subsection{Metot}

Bu çalışma kapsamında, iş sağlığ́ ve güvenliği konusu ile ilgili olarak Ankara İlinde bulunan peyzaj uygulama firmalarının uygulama aşamalarında karşılaştıkları riskler ve kazaların ortaya çıkarılması amacıyla ilgili çalışanlar ile sözlü görüşmeler yapılmıştır. Bu teknik ile çalışanların konu ile ilgili görüşleri ve iş sağlığı ve güvenliği kapsamında firmanın aldığı önlemler hakkında bilgi toplanmıştır.

Çalışmada ayrıca konu ile ilgili literatür taraması yapılmıştır. Çalışmanın ilerleyen sürecinde peyzaj uygulama alanlarında iş sağlığı ve güvenliği ile ilgili mevcut durumu daha iyi anlayabilmek için bir park yapım şantiyesi araştırmamıza model olacaktır. Çankaya Belediyesi Park Bahçeler Müdürlüğü ile görüşme sağlanmış ve eş zamanlı başlayacak olan üç adet mahalle parkı uygulama projeleri bilgisi alınmıştır. Belediye çalışanları olarak peyzaj mimarları ile görüşülerek, projeler ve uygulama süreçleri ile ilgili bilgileri alınmıştır. Üç parkın uygulama projeleri incelenmiş ve üçü de aynı büyüklükte ve tümünde aynı malzemeler kullanılarak uygulama yapılacağı tespit edilmiş ve aralarında ulaşım açısından en kolay olan Oran şantiyesi seçilerek alan gözlemleri ve sözlü görüşmelere başlanmıştır.

2016 yılında ihale edilen park proje uygulaması aynı yılın Nisan ve Temmuz ayları arasında yapılmıştır. Nisan ayından itibaren her hafta alana gidilerek gözlem yapılmış, fotoğraf çekilmiştir. Öncelikle firma sahibi ile görüşme sağlanmış, daha sonra şantiye şefi peyzaj mimarı ile ve diğer çalışanlar ile görüşülmüş ve iş sağlı̆̆1 ve güvenliği üzerine fikirleri alınmıştır. Alana gidilen günlerde çalışmalarını engellememek amacıyla öğle yemeği ve dinlenme saatlerinde iş sağlığı ve güvenliği konusuna katılımcı olarak fikir beyan etmelerini sağlamak için çalışanlarla topluluk halinde sözlü görüşmeler yapılmıştır. Görüşmeler sırasında iş sağlığ1 ve güvenliği ile ilgili temel konular, iş güvenliği eğitimleri, çalışan hakları ve işverenin iş güvenliği konusuna yaklaşımı üzerine görüşleri alınmıştır.

\section{Bulgular ve Tartışma}

Bu tez çalışmasında örnek alan olarak seçilen Oran park peyzaj uygulama projesi Çankaya Belediyesi Park Bahçeler Müdürlüğünden temin edilmiştir. Oran mahallesi Esat Özoğuz sokakta bulunan park projesinin uygulama alanı 5.970 $\mathrm{m}^{2}$ dir. Projede yaklaşık $800 \mathrm{~m}^{2}$ yürüme yolu (beton bordür ve wash beton plak), toplamda $370 \mathrm{~m}^{2}$ çocuk oyun alanları, piknik alanı için her biri $7 \mathrm{~m}^{2}$ olan 6 adet ahşap kameriye, yaklaşık $60 \mathrm{~m}^{2}$ ahşap pergola ve $4600 \mathrm{~m}^{2}$ yeşil alan bulunmaktadır. Ayrıca yeşil alan içerisinde 291 adet ibreli ve yapraklı ağaç türü, 286 adet çalı türü ve 2.495 adet yer örtücü, sarılıcı bitki türü bulunmaktadır. Park alanına sınır, $80 \mathrm{~m}^{2}$ elektrik trafosu bulunmaktadır. Yoğun trafiğe sahip olmayan bir cadde üzerinde bulunan parkın etrafında site- konut ve otel bulunmaktadır (Şekil 2). 


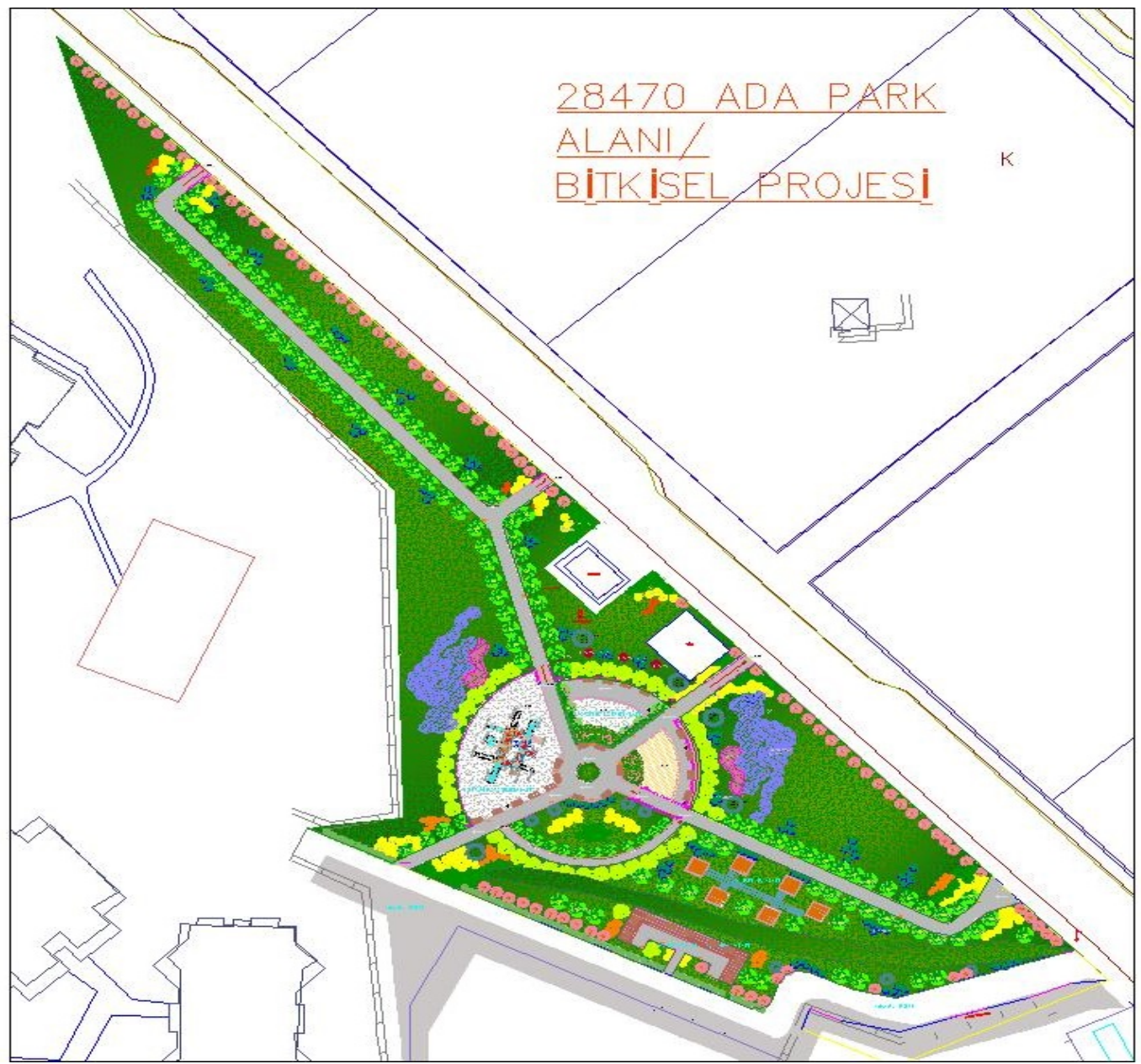

Şekil 2. Oran örnek alan peyzaj bitkisel uygulama projesi (Çankaya Belediyesi Park Bahçeler Müdürlüğü)

Proje hizmetlerinde uygulamaya esas yapılacak iş kalemlerini görmek ve iş güvenliği konusunda yapılması gereken uygulamaları tespit edebilmek amacıyla, verilen proje üzerinden iş kalemlerinin bir listesi çıkarılmıştır. Bu listeye göre kullanılacak makine ve ekipman listesi hazırlanmıştır (Tablo 4).

Tablo 4 Örnek alanda yapılacak işler ve ekipman listesi (Orijinal)

\begin{tabular}{|c|c|c|}
\hline Uygulama Süreci & Yapılacak ișler & Kullanılacak makine veya ekipman \\
\hline \multirow[t]{2}{*}{ Plan Aplikasyonu } & \multirow{2}{*}{$\begin{array}{l}\text { Arazinin topoğrafyasının kesin projeye } \\
\text { göre düzenlenmesi (Kazı-dolgu) } \\
\text { Lim bordürlerin, yürüme yollarının, } \\
\text { duvarların, merdivenlerin ve pergola altı } \\
\text { beton döşemelerin yapımı } \\
\text { Sulama hatlarının kazılması ve döşenmesi } \\
\text { (kaynak işleri) }\end{array}$} & Küçük JCB kepçe, kamyon \\
\hline & & $\begin{array}{l}\text { Demir, beton dökümü için kalıp-tahta, taş bordür, wash } \\
\text { beton blok taş, hasır çelik, stabilize malzeme, teraziler, } \\
\text { kürek, mala vb. gibi el aletleri, kompaktör. } \\
\text { Füzyon kaynak, kazma, kürek, sulama boruları ve } \\
\text { parçaları, maket bıçağ1 }\end{array}$ \\
\hline \multirow{2}{*}{ Yapısal Uygulama } & \multirow{2}{*}{$\begin{array}{l}\text { Aydınlatma için kablo döşenmesi (indirme, } \\
\text { kaldırma, montaj) } \\
\text { Çocuk oyun grubu ve pergolaların } \\
\text { yerleştirilmesi ve montajı (indirme, } \\
\text { kaldırma, montaj) }\end{array}$} & $\begin{array}{l}\text { Kamyon, hıyap, kazma, kürek, elektrik için el aletleri, } \\
\text { hilti, matkap, kablo, aydınlatma eleman, ankraj beton, } \\
\text { pano için yalıtım paspasları }\end{array}$ \\
\hline & & Kamyon, elektrikli testere, el aletleri \\
\hline \multirow{3}{*}{ Bitkisel Uygulama } & \multirow{3}{*}{$\begin{array}{l}\text { Toprak tesviyesinin yapılması } \\
\text { Bitkisel projeye uygun bitkilerin dikimi } \\
\text { (indirme, kaldırma, istifleme) }\end{array}$} & Kazma, kürek, tırmık, el arabası \\
\hline & & Forklift, kamyon, Kazma, kürek, \\
\hline & & $\begin{array}{l}\text { Çim tohumu, kapak toprağı (gübreli), kamyon, el arabası } \\
\text { tırmık, silindir }\end{array}$ \\
\hline
\end{tabular}

Şantiye alanında yapılacak işlere göre çeşitli uzmanlıkta çalışanlar (taş-duvar ustası, elektrik ustası, sulama ustası, kalıp ustası, iş makinesi operatörü gb.) ve ayrıca vasıfsız işçiler bulunmaktadır. Çalışanları yapacakları işe yönlendirmek ve organize etmek için çalışan temsilcisi (formen) veya temsilcileri bulunmaktadır. Formen, arazi ve 
çalışma düzenini kontrol altında almakla yükümlüdür. Yapısal ve bitkisel uygulamalar için farklı çalışan temsilcileri görev almaktadır. Ayrıca, çalışan temsilcisi işveren ile çalışanlar arasındaki iletişimi sağlamakla da yükümlüdür.

Uygulama sürecine başlamadan önce, yapılması gereken İSG planlamasına göre ilk olarak acil kaçış yönleri için levhalar yerleştirilmeli ve acil durumlarda toplanacak alan belirlenmelidir. Çalışanların dış etkenlerden zarar görmemesi için çalışma sahası içerisindeki tehlikelerden dışarıdaki insanları korumak için öncelikle çalışma sahası çeşitli konstrüksiyondan oluşan çevreleme elemanları ile koruma altına alınmalıdır. Gözlem yapılacak park alanının yola sınır olması nedeniyle araç trafiğini kontrol altına almak için dubalar yerleştirilmeli ve bir işaretçi yerleştirilmelidir.

Yukarıda bahsedilen ve İSG kapsamında alınması gereken şantiye alan önlemlerine rağmen, gözlem yapılan Oran şantiyesinde park alanında girişi ve çıkışı düzenleyici, dışarıdan ve içeriden gelebilecek herhangi bir tehlikeyi önleyebilecek koruma alanları yaratılmadığı gözlenmiştir. Çalışan iş makinesinin yeterli manevra alanına sahip olmaması yüzünden, çalışma esnasında yola çıktığı görülmüş ve herhangi bir uyarı ya da işaretçi olmadığ gözlenmiştir (Şekil 3).
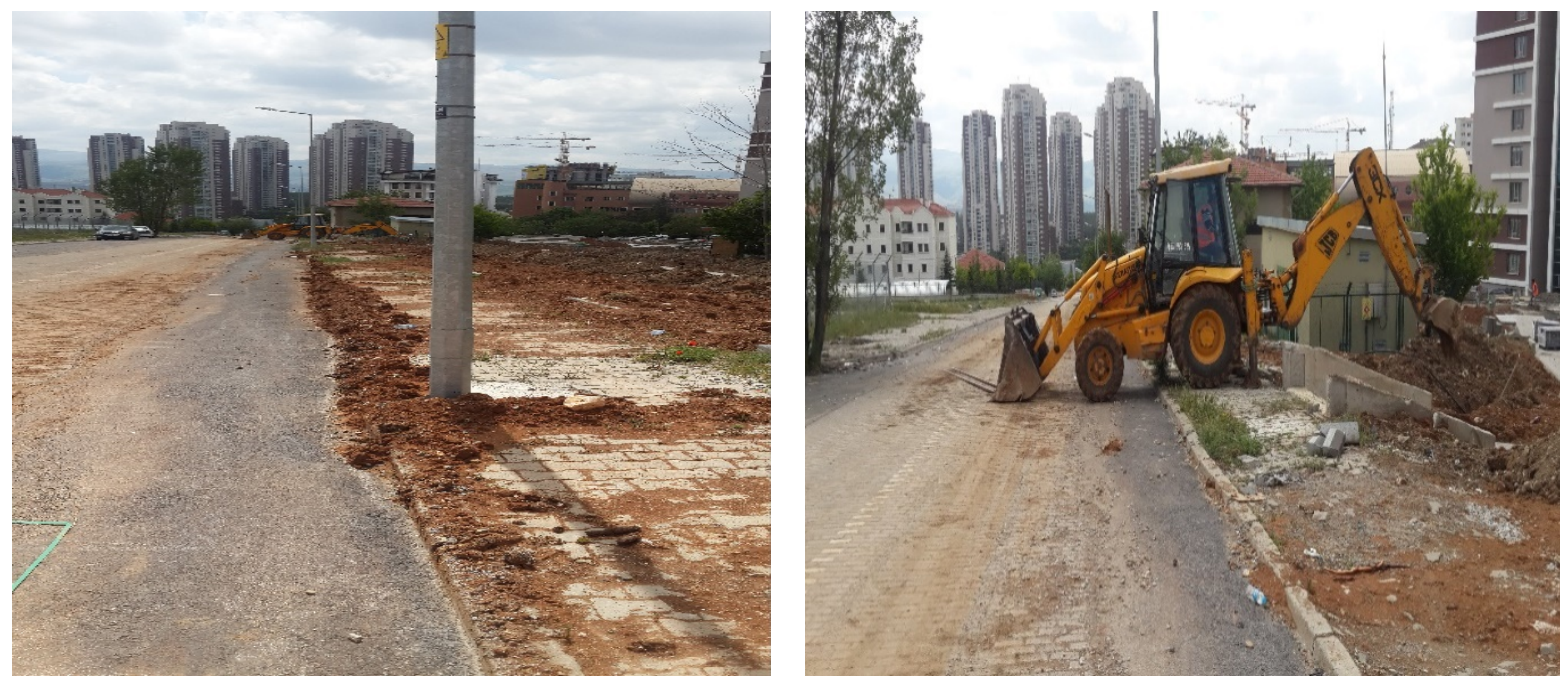

Şekil 3. Örnek park uygulama fotoğrafları (Orijinal 2016)

Oran parkı uygulama sürecinde Şekil 3'te de görüleceği gibi iş makineleri ile çalışma sırasında gerekli güvenlik işaretlemelerinin ve levhalarının (iş makinesi üstüne ve dışarıdan görülebilecek ölçüde ve mesafede 25 metre levhaları gibi) yerleştirilmediği tespit edilmiştir.
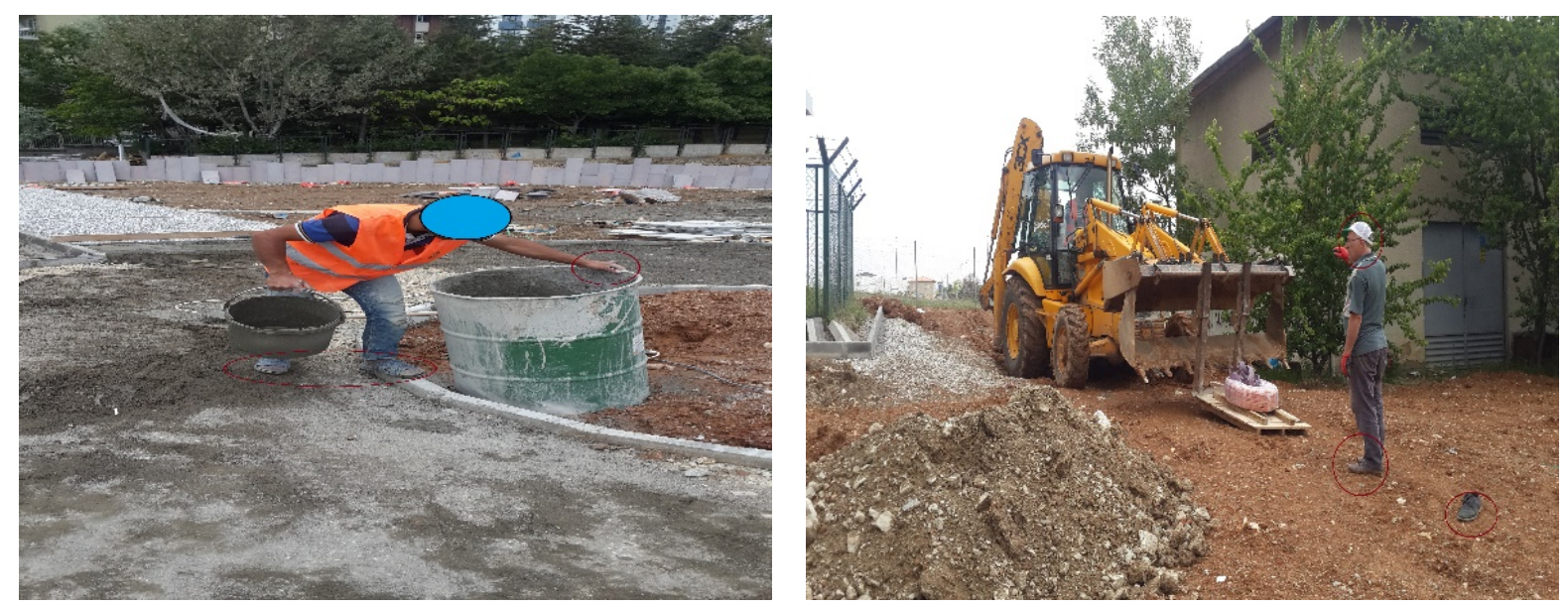

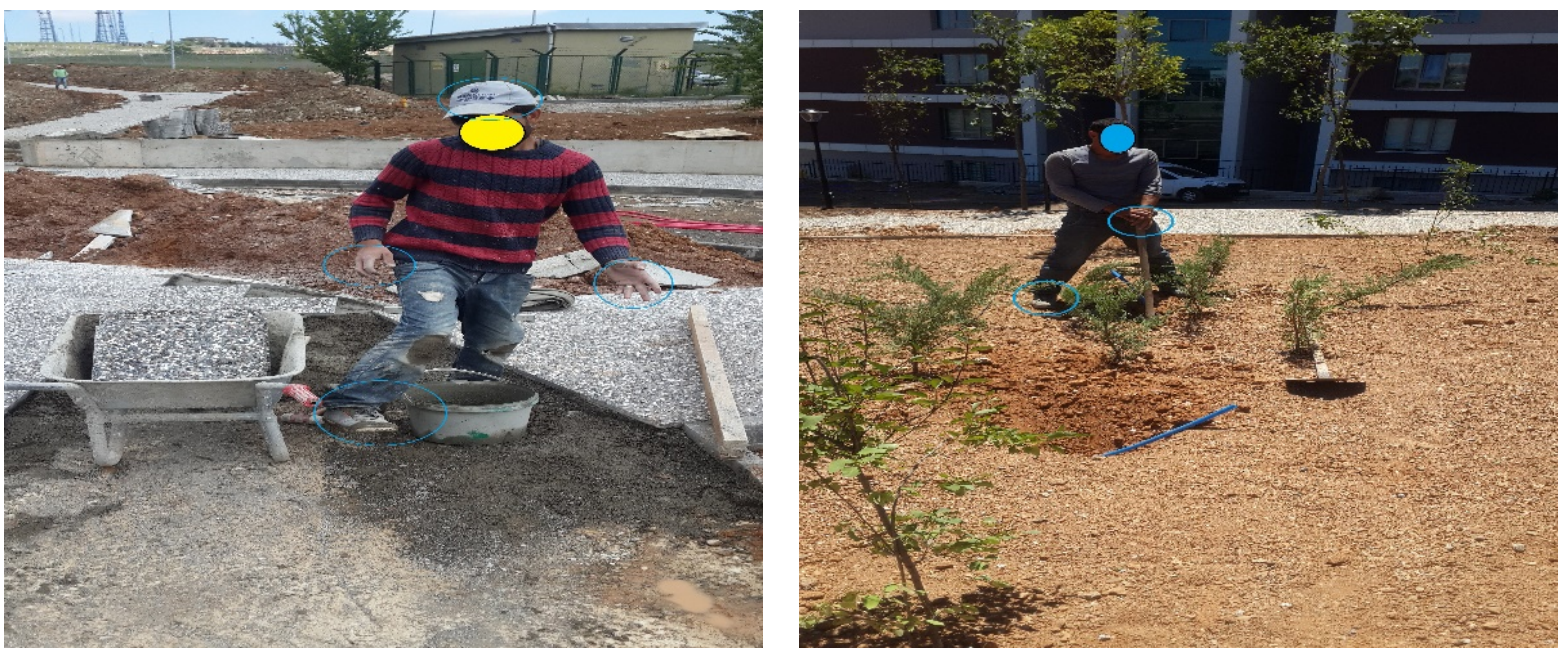

Şekil 4. Örnek park uygulama fotoğrafları devamı (Orijinal 2016)

Yapısal uygulama kapsamında yapılan yürüme yollarında kullanılan blok taşlarla yapılan çalışma sırasında ve kazma-kürek çalışmaları esnasında iş güvenliği ayakkabısı giyilmediği, eldiven takılmadığı, kişisel koruyucu ekipman kullanılmadığı gözlenmiştir (Şekil 4).
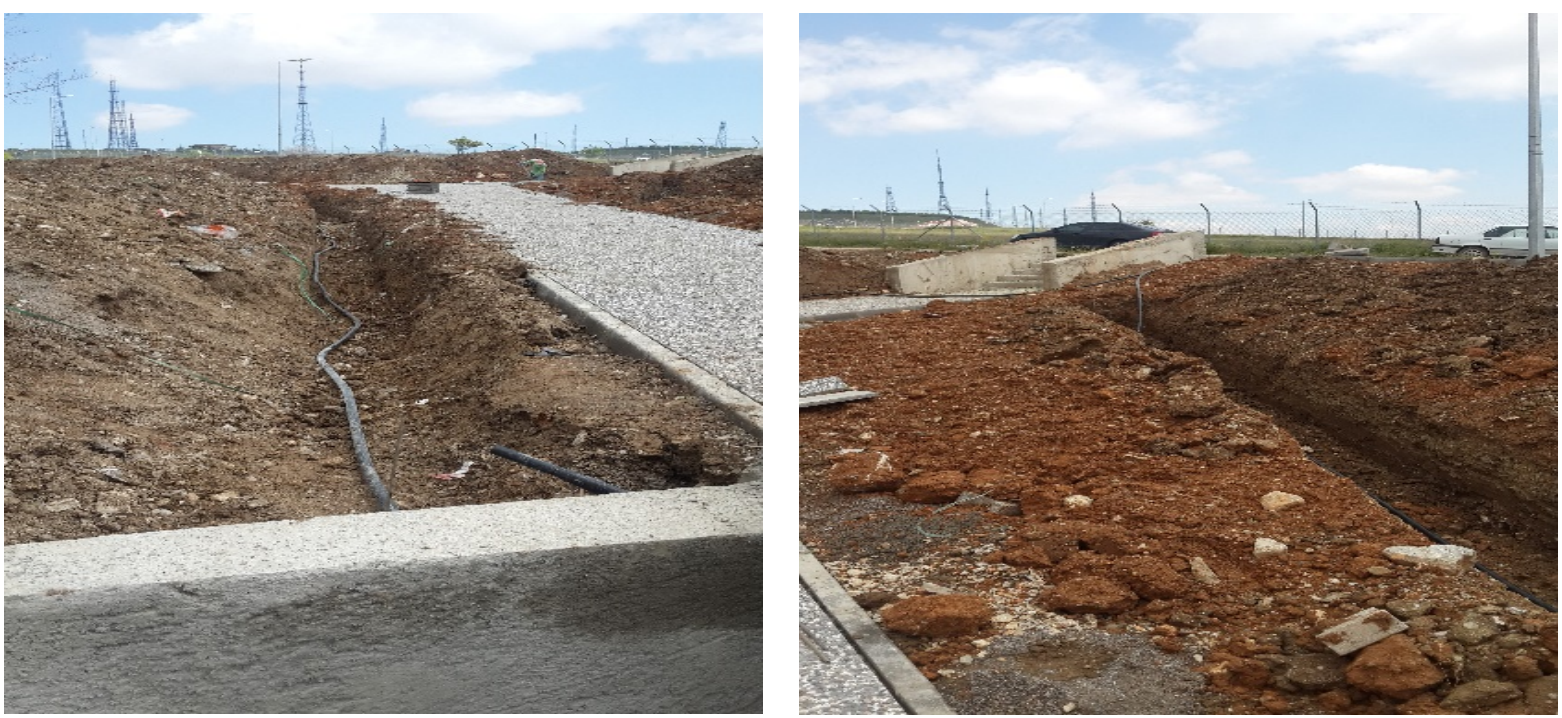

Şekil 5. Örnek park uygulama fotoğrafları (Orijinal 2016)

Alanda sulama sistemi kurulumu için kanallar açılmıştır. Kanalların aynı gün içerisinde kapatılmaması nedeniyle personelin ya da alan kullanıcılarının çukurlara düşme riski vardır. Bunun önlenmesi adına gerekli koruma hattının çekilmediği tespit edilmiştir (Şekil 5). 

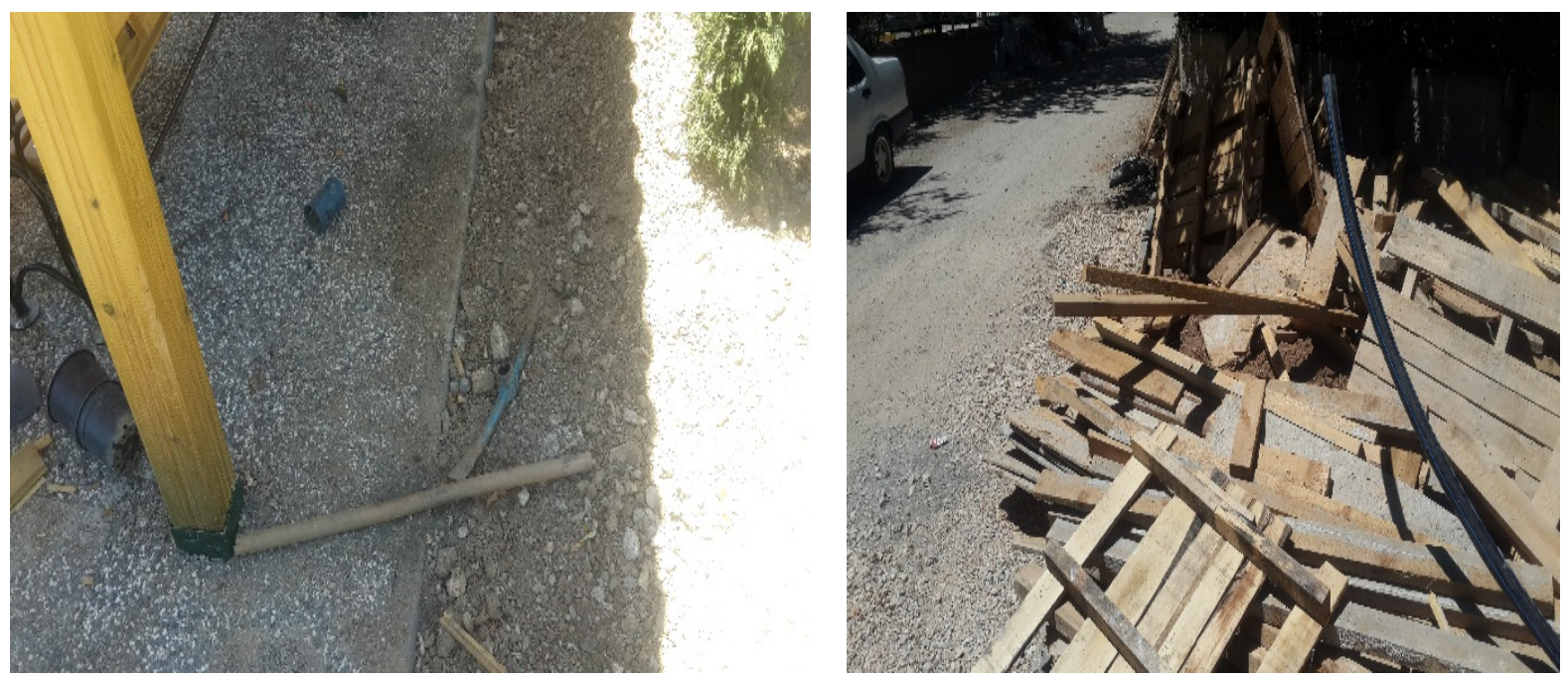

Şekil 6. Örnek park uygulama fotoğrafları (Orijinal 2016)

Çalışma alanında kullanılan ekipmanların kullanım sonrası ortamdan uzaklaştırılmadığı, kazaya neden olacak şekilde çalışma sahası içerisinde bırakıldığı gözlenmiş̧tir (Şekil 6). Güvenlikli bir depo alanı oluşturularak, kullanım aşamasında tüm malzemelere ulaşımın kolaylaştırıldığı bir sistem geliştirilerek düzen oluşturulmalıdır.

Bu çalışma kapsamında gözlem yapmak amacıyla seçtiğimiz örnek alanda gözlem ve görüşmeler ışığı altında hem işverenin hem de çalışanların iş sağlığı ve güvenliği ile ilgili eğitim almadığı tespit edilmiştir. İşs sağlığı ve güvenliği mevzuatına dair yüzeysel bilgileri olduğu ve sahada bu bilgileri kullanmadıkları gözlemlenmiştir. Yapılan gözlemler sonucunda özellikle kişisel koruyucu ekipmanların kullanılmadığı tespit edilmiştir. Gözlemlere ve görüşmelere dayanılarak yapılan karşılaştırmaya göre örnek alanda İSG planlamasının yapılmadığı, gerekli işaret ve levhaların yerleştirilmediği, alan temizliği yapılmadığı (tehlike yaratacak malzemelerin alandan uzaklaştırılması gibi) tespitinde bulunulmuştur.

Örnek alanda çalışma yapan firmanın sahibi ile 23.05.2016 tarihinde yapılan sözlü görüşmede kendisinin ve firma isminin kullanılmamasını tercih ettiğini belirtmiş̧tir. Kendilerine iş sağlı̆̆ı ve güvenliği ile ilgili düşünceleri sorulmuştur. Firma sahibi; Türkiye'de iş sağlı̆̆ ve güvenliği konusunun tam olarak işlevsel hale gelmediğini belirtmiştir. Ayrıca herhangi bir OSGB' ye verilmesi gerekenin altında bir ödeme karşıllı̆ı sadece herhangi bir denetim olması ihtimaline karşı gerekli evrakların hazırlanmasının yeterli olduğunu söylemektedir. Firma olarak kendilerinin de yüzeysel olarak iş güvenliği konusunda çalışmalar yaptıklarını, herhangi bir kazanın gerçekleşmeyeceğine emin olduklarını (konuyu basite indirgemesinden kaynaklı), gerçekleşen ramak kala olayları ya da hafif yaralanmalı kazaların da rutin bir süreç olarak değerlendirip, çok dikkate almadıklarını belirtmiştir. Ayrıca çalışanlara iş güvenliği eğitimi verildiğini belirtmiştir. Kişisel koruyucu ekipmanların çalışanlar tarafindan kullanılmadı̆̆ı gözlemi üzerine, tehlikeli bir durumun söz konusu olmadığını söyleyerek, 'bir şey olmaz' cümlesini kullanmıştır.

Parkın yapımını üstlenen firmanın çalışan temsilcisi ile 7.06.2016 tarihli sözlü görüşmede kendisine iş sağlığı ve güvenliği üzerine eğitim alıp almadıkları, yaptıkları uygulamalarda iş güvenliğine verilen önemin derecesinin ne olduğu ve Türkiye' deki uygulamalar için düşünceleri sorulmuştur. Çalışan temsilcisi; konu ile ilgili bilgisinin olduğunu fakat çalışı̆ğ 1 alanlarda (şantiyelerde) uygulamalı olarak yaşamadığını belirtmiştir. Ayrıca işverenin iş güvenliği amaçlı hiçbir önlem almak istemediğini, ilave bir maliyet yaşamak istemediği için iş güvenliği konusu ile ilgili eğitim almadıklarını, iş güvenliği uzmanı istihdam etmediklerini ya da herhangi bir ortak sağlık güvenlik biriminden hizmet almadıklarını belirtmiştir.

22.05.2016, 03-05-06-07.06.2016 tarihinde diğer çalışanlar ile yapılan sözlü görüşmelerde çalışanlar hukuki haklarını tam olarak bilmediklerini, bilmiş olsalar bile haklarını savunacak herhangi bir kurum olduğuna inanmadıklarını belirtmişlerdir. Bu sebeplerden eğitim almalarının ya da iş güvenliği önlemlerini almanın bir fark yaratacağına inanmadıklarını ortak bir dille ifade etmişlerdir.

Birçoğu 16- 20 yaşlarında olan işçilerin konu ile ilgili fikir beyan etmekten kaçındığı ve aslında herhangi bir fikre de sahip olmadıkları gözlenmiştir. Birçoğu lise mezunu olan işçiler arasında ortaokul mezunu işçilerin de olduğu 
sözlü görüşmelerde ortaya çıkmıştır. Eğitimsizlik ve iş güvenliği gündemini takip etmemeleri konuyu tartışmaktan kaçınmalarının en önemli nedenler olarak gözlenmiş̧ir.

Fikir sahibi olanların da ülke çapında herhangi bir önlemin alınabildiğine dair inançlarının olmadığını belirtmişlerdir. İSG her ne kadar yasa ve yönetmeliklerle sürece dâhil edilse bile, işveren ve çalışanlar konuyu yasal bir süreç olarak algılamamaktadır. Yapılan gözlem, görüşme ve araştırmalar sonucunda, kanunların ve yönetmeliklerin kişi ve kurumlarca yorumlanabildiği, denetim sıklığının yetersiz kaldığı, yapılan cezai yaptırımların caydırıcı olmadığı ortaya çıkmıştır. Çalışanlara verilen eğitimlerin yetersiz olduğu, insan hayatının önemli olduğu vurgusunun yapılmadığ 1 tespit edilmiştir. İstatistiklere göre, insandan kaynaklanan kazaların en büyük nedeni işi basite indirgemedir. Yaptığı işi basit düşünerek çabuk yapmaya çalışmaktır. Bu park alanında da benzer uygulama ve yaklaşımla karşılaşılmıştır. Birçok uygulama alanlarında, eğitimsizlik sonucu oluşan kazalar, yaralanma ve ölümle sonuçlanmaktadır. Çalışanların, çalışma alanında güvenli davranışlarda bulunmaları gerekliliği iş sağlığı ve güvenliği eğitimleri ile sağlanmakta ve pekiştirilmektedir.

\section{Sonuç ve Öneriler}

Son yüzyılda bilim ve teknolojide yaşanan gelişmelerle birlikte sanayileşmede hızlı bir artış gözlenmiştir. Pek çok sanayi kolunda çok sayıda işçi uygun olmayan ve tehlikeli koşullarda çalışmak zorunda bırakılmıştır. Bu artışla beraber işyerlerinde gereken önlemlerin alınmamasına bağlı olarak iş kazalarında artış yaşanmış, meslek hastalıkları ve çevre kirliliği insan ve çevre sağlığını tehdit eder duruma gelmiştir. Bu tür sorunların azaltılması ya da önlenmesinde çalışma yaşamında iş sağlığı ve güvenliği konusunun gündeme alınması gerekmektedir.

İnşaat iş kollarına paralel olarak, peyzaj mimarlığı uygulama çalışmalarında da iş kazaları oluşma riski bulunmaktadır. Bu tür kazalar ile karşılaşma nedenleri şunlardır;

- İş güvenliği kavramının ve öneminin yönetsel anlamda ciddiye alınmaması,

- İş güvenliği konusunda bilinç oluşturmak amacıyla kapsamlı eğitim verilememesi,

- Yapılan işin risklerinin etraflıca değerlendirilmemesi,

- Alanda işin tehlike sınıfına uygun önlem alınmaması,

- Karşılaşılan olumsuzluklara karşı önlem almaya yönelik etkinliklerin yürütülmemesi,

- Çalışanların iş güvenliği konusunda bilinçlenmemesi,

- Çalışanların, can güvenliğini sağlamak amacıyla kişisel koruyucu donanım kullanmayı reddetmesi,

- Yetenek ve ruhsal olarak işe uygun olan kişinin çalıştırılmaması.

Çalışma hayatı, çalışanlar üzerinde bedensel, ruhsal ve sosyal açıdan birçok etki yaratmaktadır (Oğuz 2011). Çalışan işverenine hem kişisel hem de ekonomik açıdan bağımlıdır. İşveren çalışanı karşı karşıya kalabileceği tüm tehlikelere karşı koruma ve gözetmekle yükümlüdür. Sosyal devlet anlayışıyla da çalışanların iş kazalarından ve meslek hastalıklarından korunması için devletin teknik önlemler alması gerekmektedir. Bu sebeple, iş sağlığı ve güvenliği ile ilgili gerekli mevzuatı hazırlamak ve mevzuatın uygulanabilmesi için gerekli denetimleri yapmak devletin anayasal görevi olmaktadır. İş sağlığı ve güvenliği konusunda istenilen seviyeye ulaşılması ancak insana insan olduğu için değer vermekle; işin insana insanın da işe adaptasyonunu sağlamakla mümkün olacaktır (Medeni 2014).

İSG çalışmalarının en önemli amacı, çalışanları korumaktır. İşveren ve devlet çalışanları korumak amacıyla İSG çalışmalarını yürütmekte ve çalışanların da bu konuya sosyal diyalog çerçevesinde katkı sağlamaları gerektiği düşünülmektedir. Ancak ülkemizde çalışanların karar alma süreçlerine katılımları günümüzde hala yeterli düzeye gelememiştir (Bozkurt 1993).

Tüm uygulama hizmetleri için yapılacak planlamayla beraber İSG planlaması da yapılmalıdır. Bu planlama işe başlamadan önce (şantiye kurulumu, işe uygun işçi seçimi, ergonomik ekipman, doğru kişisel koruyucu seçimi gibi) yapılması gereken risk analizi ile daha anlaşılır hale gelmektedir. Proje hizmetlerinin aşamalarının ardından, kesindetay projelerin uygulayıc firma veya mimar-mühendise verilmesinden sonra ki yapısal ve bitkisel peyzaj uygulama sürecinde şantiye kurulumu da dâhil olmak üzere tüm konulardan önce, tıpkı inşaat uygulamalarında olması gerektiği gibi, iş güvenliği eğitimi alınmalı ve tüm çalışana iş sağlığı ve güvenliği bilinci yerleştirilmelidir.

Karşılaşılan yaralanmalı ve ölümlü iş kazalarının önlenmesi ve ramak kala olaylarının ortadan kaldırılması için, öncelikli olarak bu konudaki farkındalığın artırılmasına yönelik projeler yürütülmelidir. Bu projeler, işverenden çalışana kadar her seviyede uygulanabilir olmalı ve başta işveren olmak üzere tüm taraflar yükümlülüklerinin farkına varmalıdır. Bu da ilk olarak uygulama öncesi çalışanların yapacakları işlere özgü eğitimleri almaları ile başlamalıdır. 
Eğitimlerin sözlü anlatım yanında görsel anlatımların (resim, video vb) çalışanların dikkatini çekmesi ve bilinç oluşması yönünde etkili olması beklenmektedir. Eğitimlerin sıklığı artırılmalı ve katılım zorunlu tutulmalıdır. İşyerlerinde çalışanların tümü iş sağlığı ve iş güvenliği konusunda söz ve karar sahibi olmalıdır.

Ergonomi; insanın davranışsal ve biyolojik özelliklerini inceleyerek bunlara uygun yaşama ve çalışma alanları yaratmayı amaçlayan bir bilim dalıdır. Fiziksel çevrenin insana uygunlaştırılmasıdır. Ergonominin amacı, insanın fiziksel kullanımını, zaman kaybını, işe devamsızlığını, çalışma verimliliğini, kalitesini, güvenliğini, konforunu en süt düzeye çıkartarak kaza ve yaralanmaları önlemektir. Ergonomi, İş Sağlığı ve Güvenliği konusunun en önemli unsurudur. Disiplinler arası bir anlayış ve hizmet gerektirmektedir. İş sağlı̆̆ı ve iş güvenliği tedbirleri almak amacıyla işyeri ortamı, kullanılan teknoloji, üretimde kullanılacak hammadde, ergonomi ile ilgili konular proje aşamasında planlanmalı ve bununla ilgili çalışmalar yapılmalıdır.

Peyzaj mimarlarının iş tanımının Türkiye' de henüz yeterince anlaşılmamış olması, uygulama hizmetlerinde herhangi bir standarda sahip olmamasının, küçük ölçekli peyzaj uygulama hizmeti veren firmalarda peyzaj mimarları çalıştırılmıyor olmasının en önemli nedenlerinden biri Peyzaj Mimarları Odasının resmî kurumlarla ve oda üyeleri ile olan iletişimini tam olarak sağlayamaması olarak görülmektedir. Peyzaj Mimarları Odası (PMO)'nın da gereken önlemleri alması, kontrol ve yaptırımları uygulaması beklenmektedir. Ancak henüz Odanın ve Bakanlığın uygulama süreçlerini tanımlayan, standartları oluşturan bir çalışmasına rastlanmamıştır. Bu konuda hem araştırmacı olarak üniversitelere, kontrol ve yaptırım mekanizmalarını işleten Bakanlıklara, gereken çalışmaları ve örgütlenmesi gereken PMO'na ve özellikle müteahhit, yönetici ve çalışanlara büyük iş düşmektedir. İş güvenliği çalışanın sağlığını, hayatını ve refahını korumayı amaçlamaktadır. Bu kapsamda hem peyzaj mimarlığı uygulama sürecinin tam olarak anlaşılabilmesi hem de insan hayatını ve refahını korumanın öneminin daha bilinçli hale gelmesi için Peyzaj Mimarları Odasının çeşitli etkinlikler (ücretsiz eğitim, tanıtım broşürleri, sempozyum, kongre vb.) yapması önerilmektedir.

2013 yılından itibaren peyzaj mimarları Bakanlığın açtı̆̆ı sınava girerek iş güvenliği uzmanı olma hakkı kazanmıştır. Peyzaj mimarlarının iş güvenliği eğitimleri alarak, uzman olmaları teşvik edilmelidir. Peyzaj mimarlığı uygulama hizmetlerinde, peyzaj mimarlarının iş güvenliği uzmanı olarak çalışmaları sağlanmalıdır. Üniversitelerin mühendislik ve mimarlık bölümlerinin bulunduğu fakültelerde, iş sağllğı ve iş güvenliği konusu ayrı bir program olarak ele alınmalıdır. Son sınıf öğrencileri için de ders konularının içerisine alınarak, bilgi ve bilinç arttırılmalıdır.

\section{Kaynaklar}

1. Bozkurt, R. (1993). Application of Modern Accident Prevention Techniques to OAL Mines, Ankara, METU, Mining Engineering Department, M.Sc. Thesis, s. 89.

2. Çiçek, Ö. ve Öçal, M. (2016). Dünyada ve Türkiye'de İş Sağlığı ve İş Güvenliğinin Tarihsel Gelişimi. HAK-İ̧̧ Uluslararası Emek ve Toplum Dergisi (c) Cilt: 5, Y11:5, Say1: 11 (2016/1) ISSN: 2147-3668.

3. Gerek, H. N. (2008). İș Sağlığ 1 ve İş Güvenliği. Eskişehir: Anadolu Üniversitesi AÖF Yayınları.

4. Güvercinci, M. (2005). İş Sağlığı ve Güvenliği Konusunda Yeni Dönem, İşveren Dergisi, c.43, sy.9,Ankara, s.28.

5. Güyagüler, T. (2007). Kaza Önlemede Kaza Maliyet Hesaplama Modelinin Kullanımı, İş Sağlığı ve Güvenliği Dergisi, Çalışma ve Sosyal Güvenlik Bakanlığı Yayını, Sayı: 33, Yı1: 7, s. 8.

6. Keleş, R. (2004). İş Sağlığı ve Güvenliği Kavramı ve Kavramla İlgili Yeni Perspektifler. İş Sağlı̆̆ı ve Güvenliği Dergisi, Çalışma ve Sosyal Güvenlik Bakanlığı Yayını, 4 (22),16-20.

7. Kılıç, L. (2006). İşverenin İş Sağlığı ve Güvenliğini Sağlama Hükümlülüğü ve Sorumluluğu, Yetkin Yayınları, Ankara.

8. Medeni, D.B. (2014). İş Sağlığı ve Güvenliği Kapsamında Sorumluluk. Yüksek Lisans Tezi, Erciyes Üniversitesi, Sosyal Bilimler Enstitüsü, Özel Hukuk Ana Bilim Dalı, Kayseri.

9. Oğuz, Ö. (2011). AB Direktifleri ve Türk İş Hukukunda İş Sağlığı ve Güvenliğinde İşve-renlerin Yükümlülükleri ve İşçilerin Hakları. Legal Yayıncılık. Eskişehir.

10. URL-1 (2016). https://www.who.int/occupational_health/globstrategy/en/, (Erişim Tarihi: 08.11.2016).

11. URL-2 (2015). http://www.mmo.org.tr/dokuman/isg_raporu_2015.pdf (Erişim Tarihi: 21.09.2016)

12. URL-3 (2015). http://www.plantdergisi.com/yazi-prof-dr-oguz-yilmaz-133.html (Erişim Tarihi: 11.05.2017).

13. URL-4 (2016). www.mevzuat.gov.tr/MevzuatMetin/yonetmelik/9.5.16909-Ek.xls (Erişim Tarihi: 08.11.2016).

14. URL-5 (2016). http://www.peyzaj.org.tr/genel/bizden_detay.php?kod=5907 (Erişim Tarihi: 01.11.2016).

15. URL-6 (2016). http://www.sgk.gov.tr/wps/portal/sgk/tr/kurumsal/istatistik/sgk_istatistik_yilliklari (Erişim Tarihi: 05.01.2017).

16. Ünsar, A.S. (2003).Türkiye'de İşçi Sağlığı ve İş Güvenliği Uygulamalarının Mevcut Durumu ve Konuyla İlgili Yapılan Bir Araştırma, İstanbul, İ.Ü. Sosyal Bilimler Enstitüsü, Doktora Tezi (basılmamış), s. 277. 
17. Yılmaz, F. (2009). Avrupa Birliği ve Türkiye'de İş Sağlığı ve Güvenliği: Türkiye'de İş Sağlığ1 ve Güvenliği Kurullarının Etkinlik Düzeyinin Ölçülmesi. Doktora Tezi, İstanbul Üniversitesi, Sosyal Bilimler Enstitüsü, Çalışma Ekonomisi ve Endüstri İlişkileri Ana Bilim Dalı, 382, İstanbul. 